Brit. Heart f., 1968, 30, 38.

\title{
Haemodynamic Effects of Isopropylnoradrenaline Sulphate (Isoprenaline) Following Aortic Valve Homograft Replacement
}

\author{
LEON RESNEKOV, RICHARD FORDHAM, AND DONALD ROSS \\ From the Institute of Cardiology, National Heart Hospital, London W.1; and the Medical Unit, St. Thomas's \\ Hospital, London S.E.I
}

Isopropylnoradrenaline sulphate (isoprenaline) is a sympathomimetic drug having an action predominantly on the $\beta$-receptors of the sympathetic system (Moran, 1963). It has been shown in normal man to have positive inotropic and chronotropic actions on the myocardium, producing increases in heart rate, stroke volume, and cardiac output (Weissler, Leonard, and Warren, 1959). The drug is used extensively following heart operations, and this investigation is an attempt to clarify its action following aortic valve replacement.

\section{SubJeCtS AND METHOdS}

Six patients were studied 16-20 hours after aortic valve homograft replacement performed under high-flow hypothermic (above $30^{\circ} \mathrm{C}$.) cardiopulmonary bypass (Table I). Catheters were placed in both atria and the pulmonary artery as previously described (Fordham and Resnekov, 1967). Systemic arterial pressures were measured through a fine teflon catheter (TF 10) introduced into the brachial artery by the technique described by Seldinger (1953) and advanced into the aorta. Pressures were recorded using a strain gauge (Statham P 23 G) and oscillographic recording system (Sanborn model 296), and were referred to a point in the anterior axillary line at the level of the fourth chondro-sternal junction. Patients were sedated with intravenous papaveretum (5 mg.), and were in the supine position throughout the investigation with the upper part of the body tilted head up by $15-30^{\circ}$.

Data were obtained before isoprenaline infusion, and during each dosage increment administered into a peripheral vein using a constant rate infusion pump (C. F. Palmer, (London) Ltd.) for a period of at least $10 \mathrm{~min}$ utes before and during each study. It was judged that a steady state had been reached when no further change in pulse rate occurred. A series of pressure recordings was made at each increment and blood samples from the pulmonary artery and the aorta were withdrawn during a

Received January 6, 1967. two or three minute expired air collection, into siliconized syringes, the dead spaces of which had been filled with heparin. Expired air was analysed using a LloydHaldane gas-analysis apparatus, and passed through a Parkinson-Cowan dry gas-meter to obtain its volume. The blood samples were analysed for oxygen content from the values of percentage saturation as measured on a Kipp and Zonen haemoreflector (Brinkman and Zylstra, 1949) and haemoglobin as measured by a spectrophotometer, a correction being made for dissolved oxygen. In our laboratory this method has been found to agree to within \pm 2 per cent with the oxygen content as measured by the van Slyke manometric technique (J. Manders and R. Sillett, 1966, personal communication).

Cardiac outputs were calculated by the direct Fick method. The following formulae were used to derive other circulatory values:

$$
\begin{aligned}
& \text { LVSWI }=(\text { MAP }- \text { MLAP }) \times S I \times 13.6 \times 10^{-3}, \\
& \text { LVMWI }=\text { LVSWI } \times \text { HR } \times 10^{-3}, \\
& \text { TPR }=\frac{(\text { MAP }- \text { MRAP }) \times 80}{\text { CO }} \\
& \text { PVR }=\frac{(\text { MPAP }- \text { MLAP }) \times 80}{\text { CO }}
\end{aligned}
$$

where $\mathrm{CO}=$ cardiac output $(1 . / \mathrm{min}$.); $\mathrm{HR}=$ heart rate (beats/min.); SI = stroke index (ml./m. $\left.{ }^{2}\right) ; \mathrm{LVMWI}=$ left ventricular minute work index (kg.m./m. $\left.{ }^{2}\right)$; LVSWI $=$ left ventricular stroke work index (g.m./m. ${ }^{2}$ ); MAP = mean aortic pressure (mm.Hg); $M P A P=$ mean pulmonary arterial pressure $(\mathrm{mm} . \mathrm{Hg}) ; \mathrm{MRAP}=$ mean right atrial pressure $(\mathrm{mm} . \mathrm{Hg}) ; \mathrm{MLAP}=$ mean left atrial pressure (mm.Hg); $P V R=$ pulmonary vascular resistance (dynes. sec. $\mathrm{cm}^{-5}$ ); and $\mathrm{TPR}=$ total peripheral resistance (dynes. sec.cm. ${ }^{-5}$ ).

\section{RESULTS}

The average values of measured and calculated parameters for control studies and for studies at a dosage of isoprenaline $0.75 \mu \mathrm{g} . / \mathrm{min}$. are shown in Table II. The infusion of isoprenaline resulted in 38 
TABLE I

CLINICAL DETAILS OF SIX PATIENTS STUDIED

\begin{tabular}{|c|c|c|c|c|c|c|}
\hline Patient & $\underset{\left(\mathbf{m} .^{2}\right)}{\text { B.S.A. }}$ & $\underset{\text { sex }}{\text { Age and }}$ & Disease & Operation & $\begin{array}{l}\text { Condition } \\
\text { during } \\
\text { study }\end{array}$ & Rhythm \\
\hline J. E. & $1 \cdot 81$ & $39 \mathrm{M}$ & Aortic stenosis and regurgita- & Aortic valve homograft & Good & Sinus \\
\hline G. L. & $1 \cdot 61$ & $49 M$ & Aortic regurgitation & Aortic valve homograft & Good & $\begin{array}{l}\text { Sinus; occasional ventricular } \\
\text { ectopic beats at dose of }\end{array}$ \\
\hline & $1 \cdot 64$ & & Aortic stenosis and regurgita- & Aortic valve homograft; & Good & Sinus; occasional ectopic beats \\
\hline G. G. & $1 \cdot 84$ & $54 M$ & $\begin{array}{l}\text { Aortic regurgitation and } \\
\text { stenosis }\end{array}$ & Aortic valve homograft & Good & $\begin{array}{l}\text { Sinus; occasional ventricular } \\
\text { ectopic beats }\end{array}$ \\
\hline D. S. & $1 \cdot 92$ & $44 ?$ & $\begin{array}{l}\text { Aortic stenosis and regurgita- } \\
\text { tion }\end{array}$ & Aortic valve homograft & Good & Sinus; nodal rhythm at dose of \\
\hline C. $\mathbf{H}$. & $1 \cdot 80$ & $41 \mathrm{M}$ & $\begin{array}{l}\text { Aortic regurgitation; mitral } \\
\text { stenosis and regurgitation }\end{array}$ & $\begin{array}{l}\text { Aortic valve homograft; } \\
\text { mitral valve decalcifica- } \\
\text { tion }\end{array}$ & Good & $\begin{array}{l}\text { Sinus; nodal ectopic beats at } \\
\text { dose of } 1.0 \text { and } 1.25 \mu \mathrm{g} . / \mathrm{min} \text {. }\end{array}$ \\
\hline
\end{tabular}

heart rate $(+21 \%)$, mixed venous oxygen content $(+6 \%)$, and left ventricular minute work $(+34 \%)$. Significant decreases were found in arterial oxygen content $(-4 \%)$, arteriovenous oxygen difference $(-16 \%)$, mean left atrial pressure $(-19 \%)$, and total peripheral resistance $(-14 \%)$. A small increase (not significant at the $5 \%$ level) was found in respiratory minute volume $(+6 \%)$, oxygen consumption $(+7 \%)$, stroke index $(+4 \%)$, and left ventricular stroke work $(+11 \%)$. A small nonsignificant decrease was found in mean pulmonary arterial pressure $(-3 \%)$, pulmonary vascular resistance $(-19 \%)$, and mean right atrial pressure $(-39 \%)$.

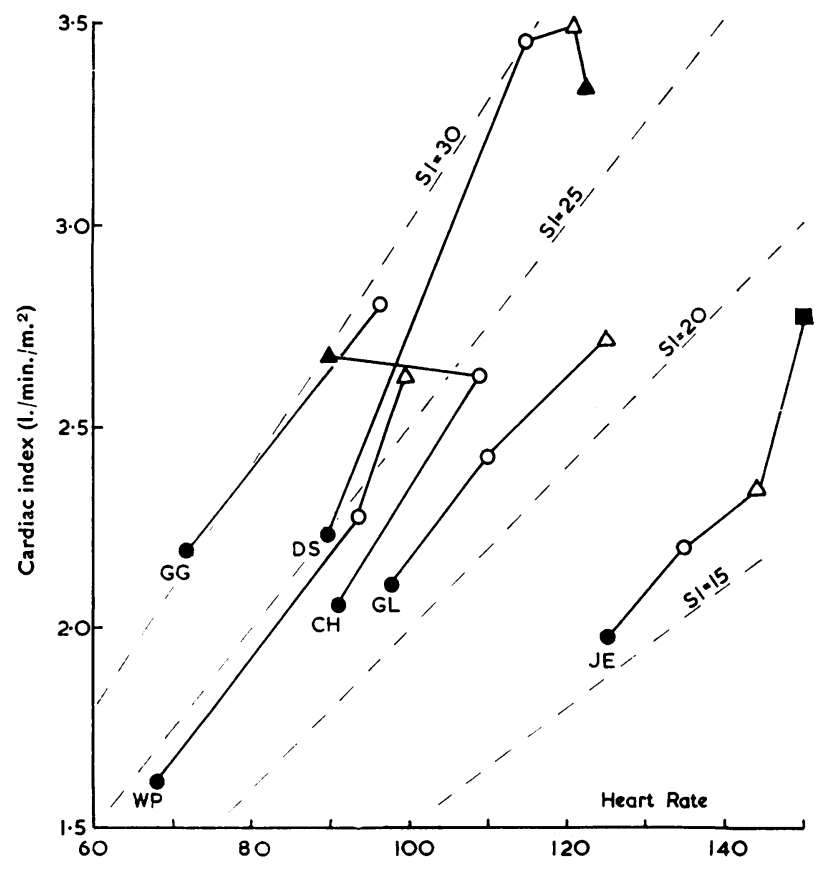

Fig. 1.-Relation between cardiac index, heart rate, and stroke index before and during isoprenaline infusion. The symbols used in this and subsequent figures refer to the following dosage levels:
$\bullet=$ control,
$\mathrm{O}=0.75 \mu \mathrm{g} . / \mathrm{min}$.,
$\Delta=1.0 \mu \mathrm{g} . / \mathrm{min} .$,
$\Delta=1 \cdot 2 \mu \mathrm{g} . / \mathrm{min}$.
$\square=1.5 \mu \mathrm{g} . / \mathrm{min}$. 
TABLE

AVERAGE VALUES BEFORE AND DURING

\begin{tabular}{|c|c|c|c|c|c|c|c|}
\hline $\begin{array}{c}\text { Isoprenaline } \\
\text { dose } \\
(\mu \mathrm{g} \cdot / \mathrm{min} .)\end{array}$ & $\begin{array}{l}\text { Resp. minute } \\
\text { volume } \\
\text { (1./min.) }\end{array}$ & $\begin{array}{l}\text { Oxygen } \\
\text { uptake } \\
\text { (ml./min.) }\end{array}$ & $\begin{array}{c}\text { Arterial } \\
\mathrm{O}_{2} \text { content } \\
(\text { vol. } \%)\end{array}$ & $\begin{array}{c}\text { Mixed } \\
\text { venous } \\
\mathrm{O}_{2} \text { content } \\
(\text { vol. } \%)\end{array}$ & $\begin{array}{l}\text { Arterio- } \\
\text { venous } \\
\mathrm{O}_{2} \text { diff.) } \\
\text { (vol. \%) }\end{array}$ & $\begin{array}{c}\text { Cardiac } \\
\text { index } \\
\left(1 . / \mathrm{m}^{2}\right)\end{array}$ & $\begin{array}{l}\text { Heart rate } \\
\text { (beats/min.) }\end{array}$ \\
\hline $\begin{array}{c}\text { Control } \\
0.75\end{array}$ & $\begin{array}{c}7.93(1.54)^{\star} \\
8.37(1.52) \\
(\text { N.S.) }\end{array}$ & $\begin{array}{c}255(33) \\
273(23) \\
(\text { N.S.) }\end{array}$ & $\begin{array}{l}16.8(1.3) \\
16 \cdot 1(1.6) \\
(p<0 \cdot 01)\end{array}$ & $\begin{array}{c}9.42(1.31) \\
9.95(1.31) \\
(p<0.01)\end{array}$ & $\begin{array}{l}7.4(0.78) \\
6.2(0.92) \\
(p<0.01)\end{array}$ & $\begin{array}{c}2.03(0.20) \\
2.63(0.44) \\
(p<0.01)\end{array}$ & $\begin{array}{c}90.0(18.9) \\
109(14 \cdot 3) \\
(p<0.01)\end{array}$ \\
\hline
\end{tabular}

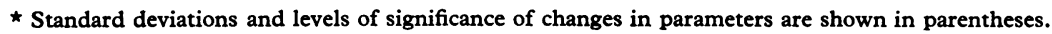

Individual results, including those at higher dosage levels, are shown in Fig. 1 to 3 . It can be seen that values found at the higher isoprenaline doses show similar but greater changes than those at a dose of $0.75 \mu \mathrm{g} . / \mathrm{min}$. Exceptions are found in patients D.S. and C.H. In patient D.S. the appearance of nodal rhythm at a dose of $1.25 \mu \mathrm{g}$. $/ \mathrm{min}$. was associated with a fall in cardiac output and stroke volume, little additional change in heart rate, and a rise in total peripheral resistance in spite of the higher isoprenaline dosage (Fig. 1 and 2). In patient C.H. the appearance of nodal ectopic beats following 50 per cent of the sinus beats (dosage level $=1.0$ and $1.25 \mu \mathrm{g} . / \mathrm{min}$.) was associated with a fall in effective pulse rate (the nodal beats produced no increase in aortic pressure) (Fig. 1), a fall in cardiac output in spite of the increased isoprenaline dosage (Fig. 2), and a rise in the average stroke volume (Fig. 1) and the mean left atrial pressure. The rise in stroke volume was presumably due in part to an increased filling pressure and diastolic filling time.

Increases in cardiac output were mainly associated with increases in pulse rate, and little change in the stroke volume occurred, except in one patient (D.S.) in whom there was a rise of $5 \mathrm{ml}$. in the stroke index. The slower the control heart rate, the greater the increase in the cardiac output and heart rate at a given isoprenaline dosage (Fig. 4), provided that sinus rhythm was maintained throughout.

No significant change in left ventricular stroke work index occurred during the infusion of isoprenaline (Fig. 3), but the left ventricular external minute work index increased considerably and was related to changes in the heart rate. In patients D.S. and C.H. a fall in the external minute work accompanied the appearance of nodal rhythm and multiple nodal extrasystoles, respectively.

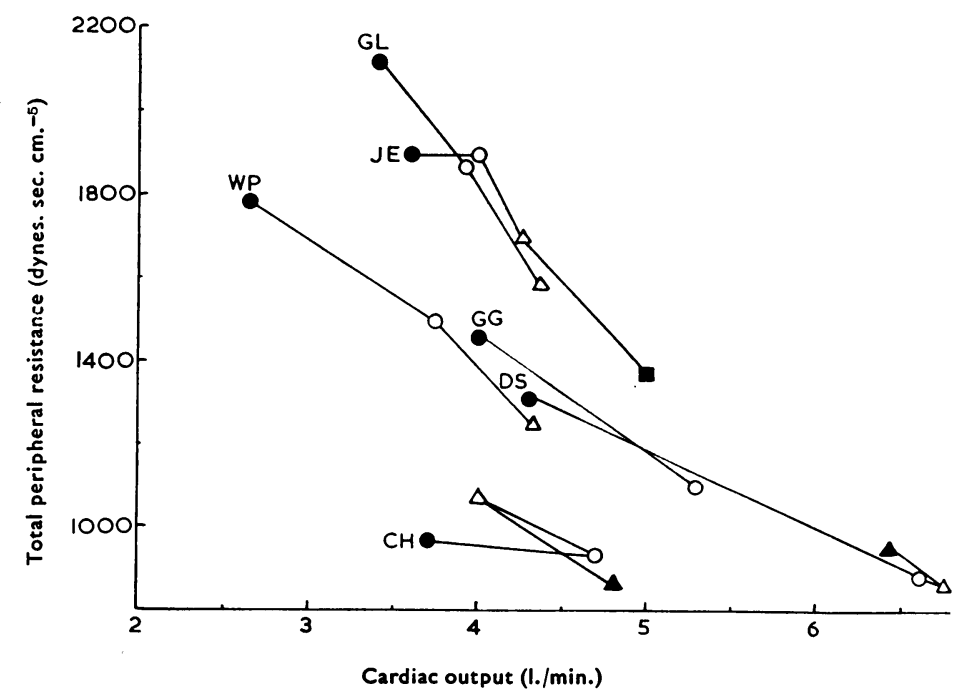

Fig. 2. - The relation between cardiac output and total peripheral resistance before and during isoprenaline infusion. Symbols as in Fig. 1. 
II

NNFUSION OF ISOPRENALINE (0.75 $\mu \mathrm{g} . / \mathrm{min}$.)

\begin{tabular}{|c|c|c|c|c|c|c|c|c|}
\hline $\begin{array}{l}\text { Stroke index } \\
\left(\mathrm{ml} . / \mathrm{m}^{2}\right)\end{array}$ & $\begin{array}{l}\text { Left ventr. } \\
\text { stroke work } \\
\text { index } \\
\left.\text { (g.m./m. } .^{2}\right)\end{array}$ & $\begin{array}{c}\text { Left ventr. } \\
\text { minute work } \\
\text { index } \\
(\mathrm{kg} \cdot \mathrm{m} . / \mathrm{min} . / \\
\left.\mathrm{m.} .^{2}\right)\end{array}$ & $\begin{array}{l}\text { Mean arterial } \\
\text { pressure } \\
(\mathrm{mm} . \mathrm{Hg})\end{array}$ & $\begin{array}{l}\text { Mean pulm. } \\
\text { arterial } \\
\text { pressure } \\
(\mathrm{mm} . \mathrm{Hg})\end{array}$ & $\begin{array}{c}\text { Mean left } \\
\text { atrial } \\
\text { pressure } \\
(\mathrm{mm} . \mathrm{Hg})\end{array}$ & $\begin{array}{c}\text { Mean right } \\
\text { atrial } \\
\text { pressure } \\
(\mathrm{mm} . \mathbf{H g})\end{array}$ & $\begin{array}{l}\text { Pulm. vasc. } \\
\text { resist. (dynes. } \\
\text { sec. } \mathrm{cm} .^{-5} \text { ) }\end{array}$ & $\begin{array}{l}\text { Total periph. } \\
\text { resist. (dynes. } \\
\text { sec. } \mathrm{cm} .^{-5} \text { ) }\end{array}$ \\
\hline $\begin{array}{c}23 \cdot 3(4 \cdot 5) \\
24 \cdot 3(4 \cdot 7) \\
(N . S .)\end{array}$ & $\begin{array}{c}21 \cdot 5(5 \cdot 4) \\
23.9(5 \cdot 1) \\
(\text { N.S. })\end{array}$ & $\begin{array}{c}1.91(0.45) \\
2.56(0.52) \\
(p<0.01)\end{array}$ & $\begin{array}{c}77(12 \cdot 5) \\
80(13 \cdot 8) \\
(\text { N.S. }) \\
\end{array}$ & $\begin{array}{c}17 \cdot 5(4.7) \\
17 \cdot 0(4.8) \\
(\text { N.S. })\end{array}$ & $\begin{array}{c}8.0(2.4) \\
6.5(1.8) \\
(p<0.05)\end{array}$ & $\begin{array}{c}6 \cdot 6(2 \cdot 8) \\
4.0(2 \cdot 5) \\
\text { (N.S.) }\end{array}$ & $\begin{array}{c}225(135) \\
190(99) \\
(\text { N.S. })\end{array}$ & $\begin{array}{c}1586(388) \\
1363(416) \\
(p<0.05)\end{array}$ \\
\hline
\end{tabular}

Note: Pressures with reference to the anterior axillary line at level of fourth chondro-sternal junctions.

The appearance of supraventricular and ventricular ectopic beats limited the dosage of isoprenaline in 5 out of the 6 patients. Except in the case of the two patients already referred to, however, the ectopic beats were infrequent and were not considered to be too numerous to interfere with the haemodynamic studies.

\section{Discussion}

The intravenous infusion of isoprenaline in normal man has been found to have profound cardiovascular effects. Its administration is associated with a rise in pulse rate, cardiac output, stroke vol- ume, left ventricular stroke work, and left ventricular minute work, and a fall in arteriovenous oxygen difference, right atrial pressure, and total peripheral resistance, and little change in the mean arterial pressure (Gorten et al., 1961 ; Dodge, Lord, and Sandler, 1960; Williams, White, and Behnke, 1963). Weissler et al. (1959) noted that the changes in cardiac output and stroke volume produced by isoprenaline were reduced with the subject tilted $60^{\circ}$ head up, and concluded that this was due to peripheral pooling of blood, and Harrison et al. (1964) noted a decline in the end-systolic and enddiastolic dimensions of the heart during its adminis-
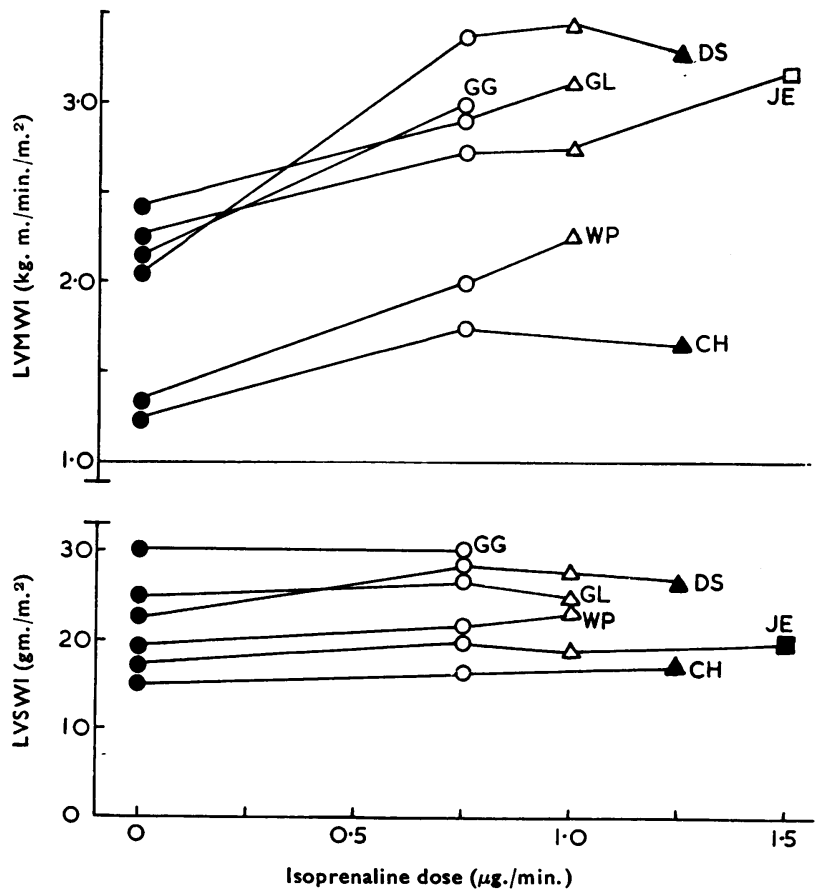

Fig. 3.-Individual values for left ventricular stroke work index (LVSWI) and left ventricular minute work index (LVMWI) before and during isoprenaline infusion. Symbols as in Fig. 1. 


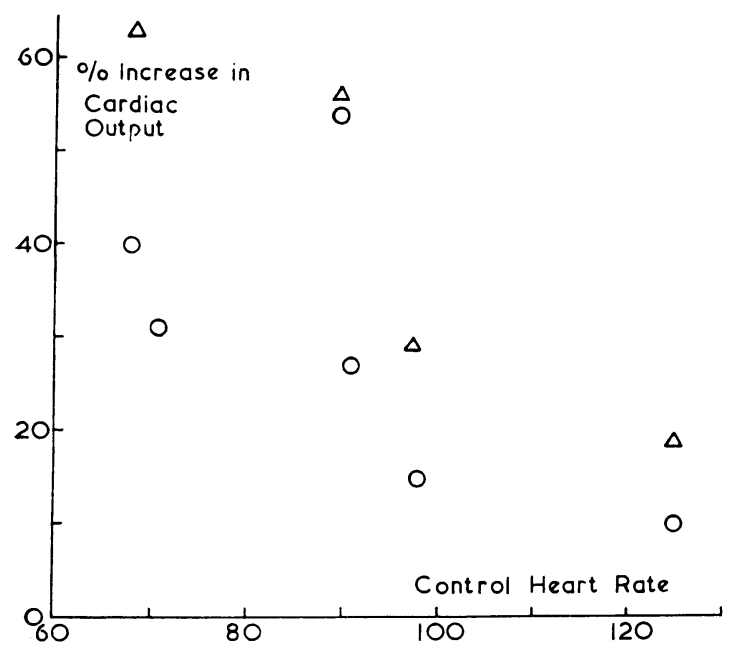

Fig. 4. - The relation between control heart rate and percentage increase in cardiac ouput during isoprenaline infusion. Symbols as in Fig. 1.

tration. Eckstein and Hamilton (1959) found that the drug reduced transmural right atrial pressure, and produced an increase in peripheral venous constriction. Similar effects to the above have been found in patients with congestive cardiac failure (Dodge et al., 1960; Dodge and Murdaugh, 1957), and in the presence of left ventricular disease (Bruce et al., 1961; Cox, Cobb, and Bruce, 1963). In patients being artificially paced at a constant heart rate, the administration of isoprenaline has been found to have a strong inotropic effect, producing large increases in stroke volume, cardiac output, and stroke work (Benchimol, Lucena, and Dimond, 1965).

The results in the present series are mainly similar to those described above, except that the dominant action of the drug on the heart was chronotropic, increases in cardiac output being associated with increases in heart rate and little alteration in stroke volume. A weak inotropic action is indicated by a constant stroke volume despite a fall in mean left and right atrial pressures. These changes were associated with a rise in left ventricular minute work, and no change in left ventricular stroke work (Fig. 3). The appearance of nodal rhythm or ectopic beats was associated with a fall in cardiac output despite an increased isoprenaline dosage.

A strong linear correlation was found between percentage changes in cardiac output and percentage changes in total peripheral resistance $(r=-0.8584$, $t=5.78, p<0.001)$, the mean arterial pressure remaining almost constant, and between percentage changes in pulse rate and percentage changes in cardiac output $(r=+0.8373, t=4.62, p<0.01)$, the stroke volume remaining almost constant. No correlation was found between isoprenaline dosage and

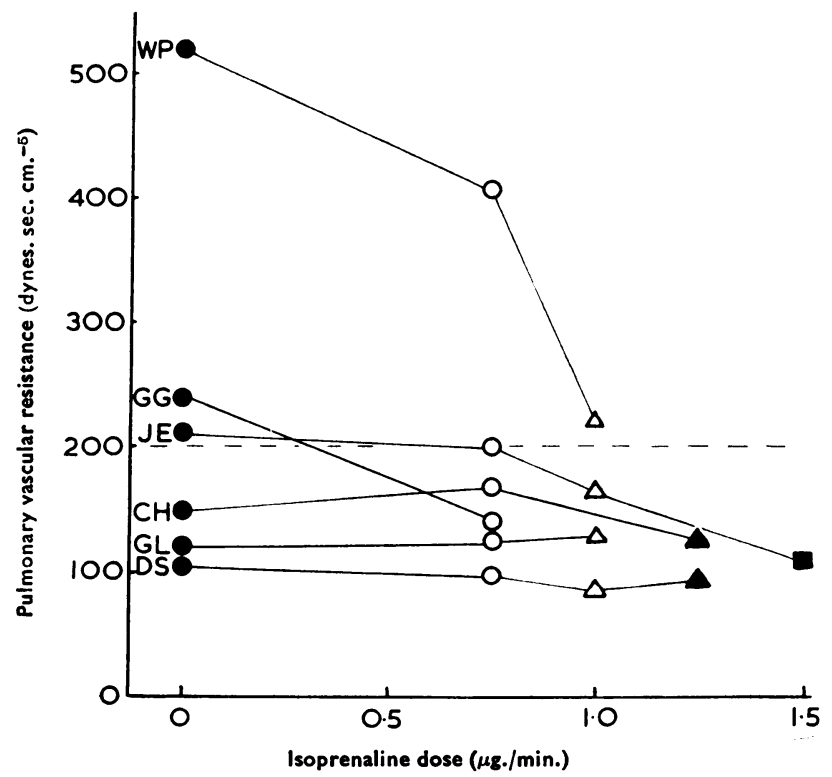

Frg. 5.-Individual values for pulmonary vascular resistance before and during isoprenaline infusion. Symbols as in Fig. 1. 
changes in cardiac output, pulse rate, or peripheral resistance. No information was obtained to indicate whether a change in pulse rate or peripheral resistance was the primary factor in determining the over-all haemodynamic changes.

The finding of Lee, Roveti, and Ross (1963) that isoprenaline administration resulted in a fall in pulmonary vascular resistance in patients in whom the initial value was above 200 dynes. sec. $\mathrm{cm} .{ }^{-5}$, but caused little change if the resistance was below this value, is confirmed in this study (Fig. 5). Isoprenaline will produce a fall in the total peripheral resistance, with no change in the blood pressure at the dosage levels studied in the present series. It should be remembered, however, that the patients we have studied have not required the drug on clinical criteria.

\section{SUMMARY}

The cardiovascular effects of the intravenous infusion of isoprenaline in the early post-operative phase following aortic valvar surgery have been studied. Increases in cardiac output were found to be directly related to heart rate and inversely related to the control heart rate; the stroke volume generally remained constant. These changes were associated with a fall in total peripheral resistance, arteriovenous oxygen difference, and left and right atrial pressures, a rise in venous oxygen content and left ventricular minute work, and no change in the left ventricular stroke work and arterial blood pressure. Isoprenaline effectively lowered the pulmonary vascular resistance when raised. The administration of higher doses frequently resulted in arrhythmias; the appearance of nodal rhythm or ectopic beats caused a fall in cardiac output despite the increased isoprenaline dosage. It is concluded that the circulatory effects of isoprenaline following homograft replacement of the aortic valve are predominantly chronotropic and only weakly inotropic.

This work was aided by a grant from the St. Thomas's Hospital Endowment Fund. We wish to thank Mr. M. Sturridge, Mr. A. Matar, and Mr. M. Kothari for placing the catheters for us, and Professor W. I. Cranston for criticizing the manuscript.

\section{REFERENCES}

Benchimol, A., Lucena, E. G., and Dimond, E. G. (1965). Stroke volume and peripheral resistance during infusion of isoproterenol at a constant fixed heart rate. Circulation, 31, 417.

Brinkman, R., and Zylstra, W. G. (1949). Determination and continuous registration of the percentage oxygen saturation in clinical conditions. Arch. Chir. Neerl., 1, 177.

Bruce, R. A., Cobb, L. A., Morledge, J. H., and Katsura, S. (1961). Effects of posture, upright exercise, and myocardial stimulation on cardiac ouptput in patients with diseases affecting diastolic filling and effective systolic ejection of the left ventricle. Amer. Heart F., 61, 476.

Cox, A. R., Cobb, L. A., and Bruce, R. A. (1963). Differential hemodynamic effects of isoproterenol on mitral stenosis and left ventricular diseases. Amer. Heart F., $65,802$.

Dodge, H. T., Lord, J. D., and Sandler, H. (1960). Cardiovascular effects of isoproterenol in normal subjects and subjects with congestive heart failure. Amer. Heart f., 60, 94.

-, and Murdaugh, H. V. (1957). Cardiovascular-renal effects of isoproterenol in congestive heart failure. Circulation, 16, 873.

Eckstein, J. W., and Hamilton, W. K. (1959). Effects of isoproterenol on peripheral venous tone and transmural right atrial pressure in man. f. clin. Invest., 38, 342.

Fordham, R. M. M., and Resnekov, L. (1967). Circulatory changes resulting from increasing the venous filling pressure by transfusion following aortic valve homograft replacement. Cardiovasc. Res., 1, 159.

Gorten, R., Gunnells, J. C., Weissler, A. M., and Stead, E. A. (1961). Effects of atropine and isoproterenol on cardiac output, central venous pressure, and mean transit time of indicators placed at three different sites in the venous system. Circulat. Res., 9, 979.

Harrison, D. C., Glick, G., Goldblatt, A., and Braunwald, E. (1964). Studies on cardiac dimensions on intact, unanesthetized man. IV. Effects of isoproterenol and methoxamine. Circulation, 29, 186.

Lee, T. D., Roveti, G. C., and Ross, R. S. (1963). The hemodynamic effects of isoproterenol on pulmonary hypertension in man. Amer. Heart f., 65, 361.

Moran, N. C. (1963). Adrenergic receptors within the cardiovascular system. Circulation, 28, 987.

Seldinger, S. I. (1953). Catheter replacement of the needle in percutaneous arteriography. A new technique. Acta radiol. (Stockh.), 39, 368.

Weissler, A. M., Leonard, J. J., and Warren, J. V. (1959). The hemodynamic effects of isoproterenol in man, with observations on the role of the central blood volume. $\mathcal{F}$. Lab. clin. Med., 53, 921.

Williams, J. F., White, D. H., and Behnke, R. H. (1963). Changes in pulmonary hemodynamics produced by isoproterenol infusion in emphysematous patients. Circulation, 28, 396. 